\title{
COMPARING THE EFFECTIVENESS OF LED TV/LCD AND WHITEBOARD AS A LEARNING MEDIA IN PBL TUTORIAL DISCUSSION IN A MEDICAL SCHOOL AT INDONESIA
}

\author{
Prattama Santoso Utomo ${ }^{1 *}$, Savitri Shitarukmi ${ }^{1}$, Noviarina Kurniawati ${ }^{1}$, Widyandana ${ }^{1}$ \\ ${ }^{1}$ Department of Medical Education and Bioethics, Faculty of Medicine, Public Health and Nursing, Gadjah Mada University, \\ Yogyakarta - INDONESIA
}

\begin{abstract}
Background: Learning media do have an important role in facilitating learning for medical students, especially in Problem Based Learning (PBL) curriculum. TV-LEDs, LCDs and whiteboards are currently popular to be used as the learning media for PBL tutorial discussions. TV-LEDs and LCDs are digital technologies which are considered more sophisticated when compared to whiteboards. Undergraduate medical students in Faculty of Medicine, Universitas Gadjah Mada (FM UGM), Yogyakarta-Indonesia attend PBL tutorials every week and use those learning media to facilitate their tutorial discussions. This study aimed to compare the effectiveness of TV-LEDs/LCDs and whiteboards as learning media in PBL tutorial discussion.
\end{abstract}

Methods: A cross-sectional study using both qualitative and quantitative (mixed method) survey approaches. A total of 398 third and fourth year undergraduate medical students of FM UGM participated the survey. Data were collected using a questionnaire that incorporated close-ended questions using likertscale (quantitative) and open-ended questions (qualitative). Quantitative data were analysed based in ARCS (Attention, Relevance, Confidence, Satisfaction) grouping method and qualitative data were analysed using deductive qualitative analysis.

Results: The survey found based on ARCS groups that $A=3,68 ; R=3,63 ; C=3,69 ; S=3,71$. These results indicate that students are eager and enthusiastic in using the technology of TV-LEDs/LCDs as learning media. The qualitative responses describe the benefits and limitations of both TV-LEDs/LCDs and whiteboards as learning media in PBL tutorial. Students also provide some suggestions to optimise the benefits of both learning medias in facilitating learning in PBL tutorial.

Conclusion: The use of TV-LEDs/LCDs as learning media in PBL tutorial received a positive response overall. TV-LEDs/LCDs are considered more effective and interactive rather than whiteboard. Students suggested that TV-LEDs/LCDs should be used side-by-side with whiteboard.

Keywords: TV-LED/LCD, whiteboard, tutorial, learning media, effectiveness, medical student

\begin{abstract}
ABSTRAK
Latar belakang: Media ajar memegang peran yang penting dalam memfasilitasi proses pembelajaran mahasiswa kedokteran, terutama pada kurikulum problem-based learning (PBL). TV-LED, LCD, dan whiteboard merupakan jenis-jenis media ajar yang memiliki kelebihan masing-masing. TV-LED dan LCD termasuk dalam golongan teknologi digital yang lebih canggih bila dibanding dengan whiteboard yang lebih sederhana dan mudah digunakan. Mahasiswa Program Studi Pendidikan Dokter di Fakultas Kedokteran Universitas Gadjah Mada melakukan PBL tutorial setiap minggunya dan selalu menggunakan media-media ajar tersebut untuk memfasilitasi diskusi tutorial mereka. Penelitian ini bertujuan untuk perbandingan efektivitas TV-LED dibandingkan dengan whiteboard sebagai media ajar dalam tutorial PBL.
\end{abstract}

*corresponding author, contact: prattama.santoso.utomo@ugm.ac.id 
Metode: Penelitian ini merupakan penelitian uji potong silang dengan pendekatan kualitatif dan kuantitatif (mixed method). Sejumlah 398 mahasiswa Prodi Pendidikan Dokter FK UGM tahun ke-3 dan ke-4 terlibat sebagai subjek penelitian. Data diperoleh melahi survey dengan kuisioner yang tersusun atas pertanyaan tertutup dengan jawaban skala likert dan pertanyaan terbuka dengan jawaban naratif (data kualitatif). Data penelitian kuantitatif dianalisis berdasar pada pengelompokan pertanyaan menurut ARCS (Attention, Relevance, Confidence, Satisfaction), sementara data kualitatif dianalisa menggunakan deductive qualitative analysis.

Hasil: Perolehan skor komponen kuisioner berdasarkan pola ARCS adalah $\mathrm{A}=3,68 ; \mathrm{R}=3,63 ; \mathrm{C}=3,69 ; \mathrm{S}$ $=3,71$. Gambaran tersebut menunjukkan antusiasme mahasiswal animo positif pengguna teknologi TV LED/ LCD sebagai media pembelajaran termasuk dalam kategori baik. Data kualitatif menunjukkan terdapat beberapa kelebihan TV-LED/LCD maupun whiteboard sebagai media ajar dalam tutorial. Terdapat pula saran-saran dari mahasiswa terkait penggunaan whiteboard maupun tutorial sebagai media ajar dalam tutorial.

Kesimpulan: Penggunaan TV LED/LCD sebagai media ajar dalam tutorial mendapat respon yang positif. TV LED/ LCD dalam tutorial dianggap lebih efektif dan interaktif dibanding penggunaan whiteboard. Mahasiswa berharap penggunaan TV LED/ LCD dapat dikombinasikan bersama whiteboard.

Kata kunci: TV-LED/LCD, whiteboard, tutorial, media ajar, efektivitas, mahasiswa kedokteran

\section{INTRODUCTION}

Problem-based learning (PBL) curriculum was established as a response to the application of modern medical education curriculum/system that should focus on self-directed, contextual, collaborative, and constructive learning. ${ }^{1}$ In PBL tutorials, medical students are expected to learn more independently, hence lecturers should be able to become facilitators to endeavour studentcentered learning. ${ }^{2}$ FM UGM has applied the PBL curriculum since 1999.

The use of learning media is important to support PBL learning processes. Learning media may facilitate learning process to maintain its quality.
Learning media enable communication and learning process between students and teachers, or between students themselves. There are six categories of learning media, namely texts, humans, objects/manipulations, visual, audio, and audiovisual. ${ }^{3}$ Each on these media has its own format to be applied as instructional materials to facilitate learning (see Table 1$).{ }^{4}$ Choosing the appropriate learning media is essential to enable a good learning environment which improves learning benefits. ${ }^{3}$ Students should be provided with student-centred learning instructions to align with the principles of PBL. The technology of learning media should not substitute the role of instructors, but to help instructors/lecturers to manage learning. ${ }^{5}$

Table 1. Examples of Learning Media, Learning Media Format, and Instructional Material ${ }^{4}$

\begin{tabular}{lll} 
Learning Media & \multicolumn{1}{c}{ Learning Media Format } & \multicolumn{1}{c}{ Instructional Material } \\
Text & textbooks, e-books, computer softwares & Textbook of Internal Medicine \\
Audio & CD, voice recordings, podcasts, TVs & Radio broadcasts \\
Visual & Drawings in whiteboard, photos, TVs & Hemostasis schemes drawed on whiteboard \\
Audiovisual & DVD, IMAX, video streaming, TVs & Films: Seven Jump in Tutorial \\
Manipulation & mannequines, virtual objects & Gynecologic examination mannequin \\
Human & Teachers/lecturers, specialists, experts & Skills instructors \\
\hline
\end{tabular}


Furthermore, Smaldino ${ }^{4}$ suggests the use of several categories of learning media to enhance students' learning quality and optimise their learning:

1. General Learning Media

It's expected that students are able to process, change, and even transmit new information: knowledge or skill.

2. Text Learning Media

Students are expected to utilize text-based information: collecting, interpreting, and communicating text-based information.

3. Computer-Based Learning Media

Students are expected to be able to operate computers, to recognize hardware and software utilities, and also to process and to take information using computer technology.

4. Distance Learning Media

Distance learning makes learning process possible when students and teachers are separated in a remarkable distance. This kind of learning media also gives us chances to optimize life-long learning because students and teachers are not obligated to meet face-toface when doing learning activities.

5. Cyber Learning Media

Internet connection is not a rare item lately. Internet connection may enhance and broaden learning. Students and teachers will be able to search learning resources using cyber learning thanks to internet.

6. Visual Learning Media

Most learning media such as textbooks, whiteboards, digital media, newspapers, books, magazines, etc. contain visual information. Students are expected to be able to interpret visual information in a better way to boost understanding in learning.

7. Audio Learning Media

Lectures and verbal information delivery are examples of audio-based learning media which play important roles in learning process. Students are expected to understand audio media more by listening to optimize learning.

8. Video Learning Media

Digital learning media can be accessed easily lately. Videos have started to be integrated in learning process, so students should be able to integrate their understanding towards video media, which is a combination of audio and visual media.

FM UGM has been utilising whiteboards as the learning media of tutorials since the beginning of PBL curriculum. Since year 2015 batch, FM UGM has started to use TV-LEDs/LCDs as a learning media in tutorial in conjunction with whiteboards. TV-LEDs and LCDs are more expensive than whiteboards, on the other hand, are also more interactive. This new learning media was expected to enhance students' learning quality. This study was conducted to learn the benefits/effectiveness of TV-LEDs/LCDs compared to whiteboards as learning media in PBL tutorial.

\section{METHODS}

This was a cross-sectional survey study using quantitative and qualitative measurements (mixed method). A survey was conducted to third-andfourth year medical students, both regular and international programmes in FM UGM. A total of 398 students participated this study to include 225 fourth-year students (154 regular students and 71 international students) and 173 third-year students (134 regular students and 39 international students).

Data were collected by asking the respondents/ subjects to fill a mixed-method online questionnaire which was distributed using GAMEL (e-learning platform). The questionnaire were adapted from the ARCS Questionnaire validated by previous research by Kebritchi. ${ }^{6}$ The questionnaire consisted of 20 close-ended questions using 5 likert-scale (1-strongly disagree to 5-strongly agree). These items incorporated five questions for each of the ARCS components, for instance Attention, Relevance, Confidence, and Satisfaction. The use of ARCS model to evaluate students' motivation has been reported in several studies. ${ }^{7,8}$ Additionally, six open-ended questions were included to explore students' perception about the advantages, disadvantages and suggestions for each of the learning media. 
Data obtained were then compiled and analysed accordingly. Close-ended questions with likertscale answers were analysed using descriptive statistics based on ARCS (Attention, Relevance, Confidence, and Satisfaction) groups to measure the mean. Open-ended answers were analysed using deductive qualitative analysis. Combining both quantitative and qualitative data was performed to corroborate data quality. ${ }^{9}$

This study has been granted the ethical clearance from the Medical and Health Research Ethics Committee, Faculty of Medicine, Universitas
Gadjah Mada. Before filling the questionnaire, respondents were explained on how they should fill the questionnaire and asked to give their informed consent.

\section{RESULTS AND DISCUSSION Quantitative components}

The quantitative component of the questionnaire showed that the learning media scored more than 3 in all of the components: $\mathrm{A}=3.68 ; \mathrm{R}=3.62 ; \mathrm{C}=$ 3.69; $\mathrm{S}=3.71$ (see Table 2).

Table 2. Quantitative Data Based on ARCS

\begin{tabular}{lcccc}
\multirow{2}{*}{ Students' Batch } & \multicolumn{4}{c}{ Questionnaire Components } \\
\cline { 2 - 5 } A (Attention) & R (Relevance) & C (Confidence) & S (Satisfaction) \\
Fourth-year (Reg) & 3.71 & 3.66 & 3.68 & 3.71 \\
Fourth-year (Inter) & 3.54 & 3.49 & 3.55 & 3.57 \\
Third-year (Reg) & 3.78 & 3.67 & 3.78 & 3.82 \\
Third-year (Inter) & 3.47 & 3.51 & 3.64 & 3.54 \\
\hline \multicolumn{1}{c}{ Overall } & 3.68 & 3.62 & 3.69 & 3.71 \\
\hline
\end{tabular}

Students' impression on the new learning media that were used for tutorial discussions (TV-LEDs/ LCDs) was considered good and enthusiastic. It was reflected from the scoring results of each Attention, Relevance, Confidence, and Satisfaction with more than 3 points. Those conditions showed students' good enthusiasm as learning media user. ${ }^{6}$

TV-LEDs/LCDs are learning media that may accommodate the use of texts, audio, visual, and video learning media formats, while whiteboards are learning media that only accommodate texts and visual learning media formats. TV-LEDs/ LCDs are categorised as more interactive. ${ }^{4}$ Another study showed that interactive learning media may attract students' enthusiasm and interest, ${ }^{3}$ enhance discussion activities and students achievement. ${ }^{10}$ Moreover, the use of TV-LEDs/LCDs would allow students to learn using video that is considered more engaging and enjoyable. ${ }^{11}$

\section{Qualitative components}

This study also obtained qualitative data alongside with quantitative data, which descripted the advantages, disadvantages, and also suggestions about these learning media. Qualitative data were clustered as seen in Table 3. 
Table 3. Qualitative Data

Categories

Whiteboard (Advantages)

\section{Responses}

- Simple, didn't need special skills, so scribers which aren't good in typing may work efficiently

- It's easier to make charts, diagrams, mind maps, it they were made manually

- Flexible and easier to be prepared

- Saving electricity and saving time

- Cheaper and didn't require special technology

- More students are involved (2 scribers)

- The field of vies in wider so it's easier to read the writings

- Scriber may give more contribution.

\begin{tabular}{|c|c|}
\hline $\begin{array}{l}\text { Whiteboard } \\
\text { (Disadvantages) }\end{array}$ & $\begin{array}{l}\text { - Scribers writings are not equal each other, sometimes hard to read them. } \\
\text { - When the whiteboard already occupied and full, it needs time to clean up the whiteboard } \\
\text { - It's tiring, we must stand up and write } \\
\text { - If the scriber slow in writing, tutorial discussion will be hampered while waiting the } \\
\text { scriber to finish writing } \\
\text { - Our hands may become dirty } \\
\text { - References in video format cannot be shared during tutorial } \\
\text { - We must re-draw pictures or schemes from the references } \\
\text { - Two scribers are needed, which may decrese discussion activity } \\
\text { - Obsolete, depends on ink }\end{array}$ \\
\hline $\begin{array}{l}\text { TV LED/LCD } \\
\text { (Advantages) }\end{array}$ & $\begin{array}{l}\text { - Typings are easier to read than writings } \\
\text { - It will be easier to share the information among tutorial group members } \\
\text { - Scribers may work easier } \\
\text { - Wouldn't need paper, marker, etc } \\
\text { - Interactive } \\
\text { - Faster, practical, and efficient } \\
\text { - We'll not be tired to stand up and write } \\
\text { - Clean and neat } \\
\text { - Rapi dan bersih } \\
\text { - Discussions run more effectively because only } 1 \text { member is subjected to be a scriber. } \\
\text { - It's possible to include pictures, flowcharts, or videos in discussion, so it'll be more } \\
\text { - interesting and interactive } \\
\text { - It's possible to browse references directly from internet, or using specific applications } \\
\text { - It's possible to correct something that already discussed while doing scroll up }\end{array}$ \\
\hline $\begin{array}{l}\text { TV LED/ LCD } \\
\text { (Disadvantages) }\end{array}$ & $\begin{array}{l}\text { - Typing skill is required, if the scriber isn't skilled, discussion process will be hampered } \\
\text { - Needs more technology and costs } \\
\text { - It'll need more time to create charts or pictures manually, for example: while making } \\
\text { 'mind mapping' } \\
\text { - PCs or laptops are needed } \\
\text { - It'll need laptops that possess HDMI port } \\
\text { - Less flexible (technical problems) }\end{array}$ \\
\hline $\begin{array}{l}\text { Whiteboard } \\
\text { (Suggestions) }\end{array}$ & $\begin{array}{l}\text { - Whiteboards should be regularly maintained and cleaned } \\
\text { - Whiteboard may be combined to TV-LED or LCD to complement each other } \\
\text { - It's already out-of-date, shouldn't be used anymore } \\
\text { - Whiteboard should be available in emergency conditions, e.g: electricity shut down } \\
\text { - Markers and erasers should be available in sufficient amount }\end{array}$ \\
\hline
\end{tabular}


Categories

TV LED/ LCD

(Suggestions)
Responses

- If it's possible, please enlarge the TV-LED size

- Please provide another type of connector, not just HDMI (so all models of laptops may be compatible)

- The quality and length of connector/s HDMI cables should be enhanced

- Tutorial minutes/notes should be standardized

- Please provide PCs or laptops in tutorial rooms

- TV-LEDs/LCDs are combined alongside with whiteboards

- Soacialization of this technology should be clear for students

- It'll be very nice if we use smartboards or touch-screen monitors.
Qualitative data above indicated a range of perception about whiteboard and TV-LEDs/LCDs performance as learning media in tutorials. Each of them has their own advantages and disadvantages. Students also gave suggestions regarding those learning media. Although TV-LEDs/LCDs are considered more interactive than whiteboards, they are not more superior to whiteboards in all aspects. Each learning media has their own advantages and also disadvantages. So, it was not considerate to take out all roles of whiteboard, then change them into TV-LEDs/LCDs. ${ }^{4}$ This study found that whiteboard was perceived as more handy as it did not require a sophisticated or complicated technology. Students might appreciate the use of whiteboard since learning media is not the only aspect to improve students' engagement. The use of appropriate facilitation methods that relevant to educational learning theories may improve students' learning experience. ${ }^{12}$ TV-LEDs and LCDs were rated as more interactive and engaging. Nevertheless, students perceived whiteboards as an obsolete, dirty, and less interactive learning media. TVLEDs and LCDs were rated as complicated and also costly. This finding is relevant with another study which points out that interactive learning media may need higher technology, more complicated and expensive. ${ }^{10}$

Students suggested to combine both TV-LEDs/ LCDs and whiteboard to be used as learning media in tutorial simultaneously. Students thought that TV-LEDs/LCDs as new learning media could be interactive. Using more than one type of learning media is acceptable and common to compensate the weaknesses of each of the learning media. ${ }^{3}$
Moreover, using more sophisticated learning media selections would improve students' experience and outcome achievement. Han et al. ${ }^{13}$ suggested that techology-enhanced learning increases outcome .expectation and learning process

The authors declare a possible limitation of this study. Although students' perception and responses on the new learning media (TV-LED/LCD) were positive and promising, the educational effect of the learning media measured in this study was students' satisfaction. Learner's satisfaction is categorized as the first level of impact in educational program evaluation. ${ }^{14}$ The higher impact such as students' achievement should also be evaluated to ensure the effectivity of the learning media.

\section{CONCLUSION}

TV-LEDs/LCDs received positive responses and enthusiasm. It was capable of enhancing learning in Attention, Relevance, Confidence, and Satisfaction aspects. TV-LEDs/LCDs were considered more interactive and effective than whiteboards. Finally, students suggested that the combination of both TV-LEDs/LCDs and whiteboards in PBL tutorials would increase engagement and effectiveness of tutorial activities.

\section{RECOMMENDATIONS}

It is important to provide training for students and tutors in using TV-LEDs and LCDs as learning media in tutorial. Since TV-LEDs/LCDs are more sophisticated, students and tutors should familiar to their features to obtain the best learning experience. Whiteboards should be used together alongside 
with TV-LEDs/LCDs to compensate each of their weaknesses.

This study was conducted based on ARCS as the base of learning media effectiveness. We suggest to use other types of questionnaire for future studies to compare the effectiveness of those learning medias. Furthermore, the impact of these learning media on students' academic achievement and learning retention should also be investigated.

\section{DECLARATION OF INTEREST}

The authors declare that there is no competing interest related to this study. Some parts of the findings of this study have been presented as an oral presentation at OTTAWA-ANZAHPE 2016 Conference in Perth, Australia.

\section{ACKNOWLEDGEMENTS}

This study received funding from 'Dana Masyarakat Fakultas Kedokteran Universitas Gadjah Mada tahun 2015'.

\section{REFERENCES}

1. Ertmer PA, Newby T. The expert learner: strategic, self-regulated, and reflective. Instruct Sci. 1996;24:1-24.

2. Calman KC. Medical education: past,present, and future: handing on learning. New York: Churchill Livingstone; 2007.

3. Clyde W, Delohery A. Using technology in teaching. New Haven: Yale University Press; 2005.

4. Smaldino SE, Lowther DL, Russell JD. Instructional technology and media for learning. Boston: Pearson Inc; 2012.
5. Dent JA. Teaching and Learning Medicine.In: DentJA,HardenRM,editors. Apractical guidefor medicalteachers[internet][citedOktober 2013]; 2001. p.7-15. Available from: http://www. vietnhim.com/nhacpho/nep/ book/092-APracticalG uideForMedicalTeachers.

6. Kebritchi M. Effect of A Computer Game on Mathematics Achievement and Class Motivation: An Experimental Study [dissertation]. Florida: University of Central Florida (Ph.D Program in Education); 2008.

7. Ying MH, Yang KT. A game-based learning system using the ARCS model and fuzzy logic. JSW. 2013 Sep 1;8(9):2155-62.

8. Huang BY, Hey KF. Measuring learners' motivation level in Massive Open Online Courses. Int J Inform Educ Tech. 2016;6(10):759-64.

9. Tavakol M, Sandars J. Quantitative and qualitative methods in medical education research: AMEE Guide No 90: Part II. Med Teach. 2014;36(10):83848.

10. Prensky L, Ashburn E, Floden R. Meaningful learning using technology: what educators need to know and do. New York: Teachers College Press; 2006.

11. Dong CY, Goh PS. Twelve tips for the effective use of videos in medical education. Med Teach. 2015;37(2);140-5.

12. Sandars J, Patel RS, Goh PS, Kokatailo PK, Lafferty $\mathrm{N}$. The importance of educational theories for facilitating learning when using technology in medical education. Med Teach. 2015;37(11):103942.

13. Han HY, Resch DS, Kovach RA. Educational technology in medical education. Teach Learn Med. 2013;25(Suppl1):S39-43.

14. Morrison J. Evaluation. In: Cantillon P, Wood D, editors. $\mathrm{ABC}$ of learning and teaching in medicine. Hoboken: John Wiley \& Sons Inc; 2010. 